\title{
Simulation of the Baiu Front in a High Resolution AGCM
}

\author{
Yoshio KAWATANI and Masaaki TAKAHASHI \\ Center for Climate System Research, University of Tokyo, Japan
}

(Manuscript received 19 November 2001, in revised form 28 October 2002)

\begin{abstract}
The features of the Baiu front are examined using an AGCM with high resolution (T106L60). The Arakawa-Schubert scheme is used for the cumulus parameterization. The model clearly simulates the eastward-moving band of rain concentrated south of Japan during June, which can be considered the Baiu front. The characteristics of the Baiu front, such as the low level jet stream, a moist neutral stratification and a strong meridional gradient of moisture, are well simulated. Meso- $\alpha$-scale disturbances appearing in the model are also comparable to the observational results.

Experiments with varying horizontal resolutions keeping the same vertical resolution are also performed to examine resolution dependences. The distribution of precipitation is improved using higher resolution. In the T106L20 experiment, the Baiu-like frontal zone is formed by using a strong gravity wave drag parameterization. The strength of the subtropical jet is important over the Baiu front for a good simulation. Experiments with two different cumulus parameterizations (the moist convective adjustment, and Kuo schemes) are performed at T106L20 resolution to examine the effect of the parameterization on the simulation of the Baiu front. The moist convective adjustment scheme leads to high rainfall in the extra tropical region. The patterns of the Indian monsoon, and the North Pacific subtropical anticyclone, are quite different from those favorable to the formation of the Baiu front. On the other hand, a better distribution of precipitation is found using the Kuo scheme. However, an earlier disappearance of the Baiu front is seen in each cumulus parameterization experiment.
\end{abstract}

\section{Introduction}

The rainy season occurs with the onset of the summer monsoon in East Asia. As a result, an intense rainfall zone is formed, which extends from west to east over the region. This rainfall zone is called the Baiu, Meiyu and Changma front in Japan, China, and Korea, respectively (and hereafter is referred to as the Baiu front). In the lower troposphere, monsoon westerly and circulation around the North Pacific subtropical anticyclone are dominant over East Asia. These circulations transport warm moist

Corresponding author: Yoshio Kawatani, Center for Climate System Research, University of Tokyo, 4-6-1 Komaba, Meguro-ku, Tokyo, 153-8904, Japan.

E-mail: kawatani@ccsr.u-tokyo.ac.jp

(C) 2003, Meteorological Society of Japan air toward the Baiu front. Ninomiya (1984) pointed out that the southwestward extension of the North Pacific subtropical anticyclone into a region of very moist tropical maritime air is the primary condition for the formation of the Baiu front around the Islands of Japan.

The Baiu front is generally characterized by a low-level jet stream, strong meridional gradients of moisture and equivalent potential temperature, and moist neutral stratification. These structures are several hundreds of kilometers in scale (Matsumoto et al. 1971; Akiyama 1973 and 1975; Ninomiya 1984, 1999 and 2000; Ninomiya and Murakami 1987; Ninomiya and Muraki 1986).

Meso- $\alpha$-scale cyclones play important roles in the Baiu front. The Baiu front looks like a quasi-stationary system in day-averaged field over several days. But the rain band actually 
consists of several meso- $\alpha$-scale disturbances. Their intervals and propagating speed are about $500-1000 \mathrm{~km}$ and $1000 \mathrm{~km}$ day $^{-1}$, respectively. They move eastward along the front and have a strong relationship with the formation of heavy rainfall (Akiyama 1984 and 1989; Ninomiya and Akiyama 1992).

It has been suggested that it is difficult to simulate the Baiu front in General Circulation Models (GCM) due to both the lack of resolution and shortcomings in the physical processes. However, it is very important to simulate the Baiu front in a GCM for forecasting the weather or future global warming.

For example, Ninomiya et al. (2001, 2002) reported the features of the Baiu front appearing in a GCM simulation. They used the CCSR/ NIES AGCM with a resolution of T42L52. The Arakawa-Schubert scheme was used for the cumulus parameterization. Their simulated Baiu front is not satisfactory in the monthlyaveraged field because of the alternation of a relatively short "Baiu phase" and a long "non Baiu phase". Although a Baiu-like frontal zone appears in the "Baiu phase", the low-level southwesterly to the south of the Baiu front, high-level $(\sim 100 \mathrm{hPa})$ northerly wind over the front and the upward motion in the rainfall zone are weaker than those in the observations in a typical Baiu period. In the "non Baiu phase", the subtropical anticyclone shifts eastward, and the monsoon westerly penetrates to $\sim 20^{\circ} \mathrm{N}, 145^{\circ} \mathrm{E}$. As a result, precipitation is formed around the region. The blocking ridge and cut-off cyclone at high latitudes are not appropriately simulated. They concluded that an accurate representation of large-scale circulation is important for simulation of the Baiu front.

The Baiu front and associated phenomena (e.g., a low-level jet stream and meso- $\alpha$-scale disturbances) may be simulated using much higher horizontal and vertical resolution. We are now able to use the GCM at higher resolution due to a recent enhancement in computational ability. A high horizontal resolution of T106 is used in the present study. We also have a higher number of layers in the vertical to satisfy the dynamical consistency between vertical and horizontal resolution (Lindzen and Fox-Rabinovitz 1989). In addition, we examined the results of lower resolution experiments to investigate the resolution dependence for simulation of the Baiu front.

Several parameterizations of physical processes such as cumulus convection are used in GCM. Good simulation of the Baiu front may also depend on such physical processes. Emori et al. (2001) reported that precipitation around the Baiu front is not sufficient in their regional model due to insufficient moisture transport from the subtropical zone. They also showed that if subtropical precipitation is suppressed by tuning the cumulus parameterization scheme, the amount of precipitation around the Baiu front increases. We also examined the features of the Baiu front in the GCM by using different cumulus parameterizations in order to investigate the parameterization dependence for simulation of the Baiu front.

This paper is the first attempt to study the Baiu front in a high resolution AGCM, comparing the features found with observational studies, and to investigate resolution and parameterization dependence in an AGCM. A description of the model is given in section 2 . Monthly-averaged features in the model are shown in section 3 . The structures of the Baiu front are shown in section 4 . Meso- $\alpha$-scale disturbances appearing in the model are described in section 5. Discussions on simulation of the Baiu front in an AGCM are presented in section 6. Summary and concluding remarks follow in section 7 .

\section{Model description}

The model used is an atmospheric general circulation model developed at the Center for Climate System Research (CCSR) and the National Institute for Environmental Studies (NIES), called the CCSR/NIES AGCM (Numaguti et al. 1997). The model is based on the primitive equations on a sphere. The spectral transform method is used in the horizontal and finite differences are used in the vertical on a sigma coordinate.

The horizontal resolution is T106, corresponding to about $1.1^{\circ} \times 1.1^{\circ}$ grids. There are 60 sigma $(\sigma)$-levels in the vertical, where $\sigma \equiv$ $P P s^{-1}, P$ is pressure, and $P s$ is surface pressure, with the top boundary at about $50 \mathrm{~km}$ altitude. The thickness of the model layers is $\sim 35 \mathrm{~m}$ in the lowest part of the troposphere, and increases gradually to $900 \mathrm{~m}$ in the middle 
troposphere and then decreases to $550 \mathrm{~m}$ in the upper troposphere and lower stratosphere. It satisfies the dynamical consistency between horizontal and vertical resolution (Lindzen and Fox-Rabinovitz 1989). Note that up to meso- $\alpha$ scale phenomena can be resolved in this simulation.

The cumulus parameterization scheme is based on Arakawa and Schubert (1974). The prognostic cloud water is computed using the scheme of Le Treut and Li (1991). The radiative transfer scheme is developed by Nakajima and Tanaka (1986) with a two-stream, k-distribution method. The Mellor-Yamada (1982) level-2 closure scheme is used for vertical diffusion. The standard gravity wave drag parameterization in the CCSR/NIES AGCM is based on McFarlane (1987). This parameterization expresses the drag of gravity waves excited by sub-grid scale mountains. However, no gravity wave drag parameterization is used in this experiment, because we used high resolution in both horizontal and vertical directions. This model can represent gravity waves more explicitly than a lower resolution model. A fourth-order horizontal diffusion with a damping time of 0.5 days at the maximum wave number is applied in this simulation. The other formations are the same as those in the standard CCSR/NIES AGCM (cf., Numaguti et al. 1997). Daily SST, which is temporally interpolated from climatology of monthly SSTs, and realistic topography are used as bottom boundary conditions. The model was integrated for 2 years with an initial condition of an isothermal atmosphere, and datasets from June of the second year are mainly analyzed.

\section{Monthly-averaged features in the model}

Figures $1 \mathrm{a}$ and $1 \mathrm{~b}$ represent the distributions of precipitation in June from observations (Xie and Arkin 1996) and the model, respectively. It is clearly seen that a concentrated rainfall zone exists in a band from China toward Japan, which is regarded as the Baiu front. The width of the heavy rainfall zone around Japan is $\sim 500 \mathrm{~km}$, which is comparable to the observations. The Inter Tropical Convergence Zone (ITCZ) in the equatorial region is also well simulated. The separation between the ITCZ and the South Pacific Convergence Zone (SPCZ)

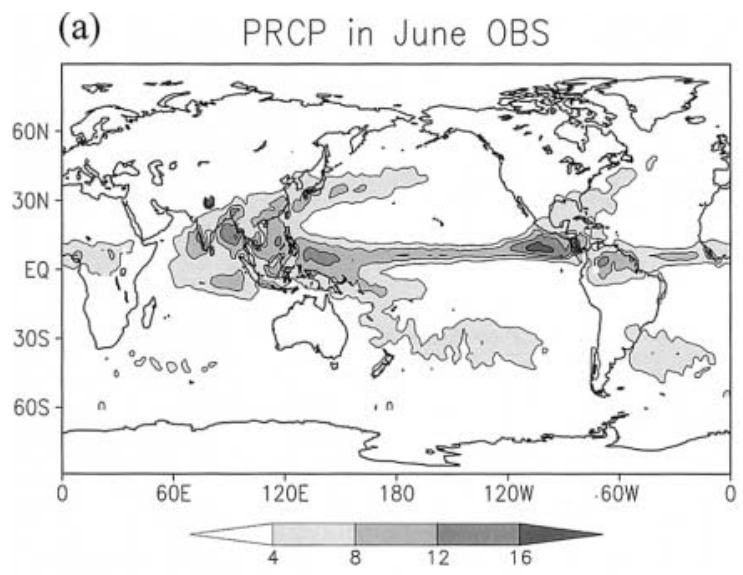

(b) PRCP in June T106L60

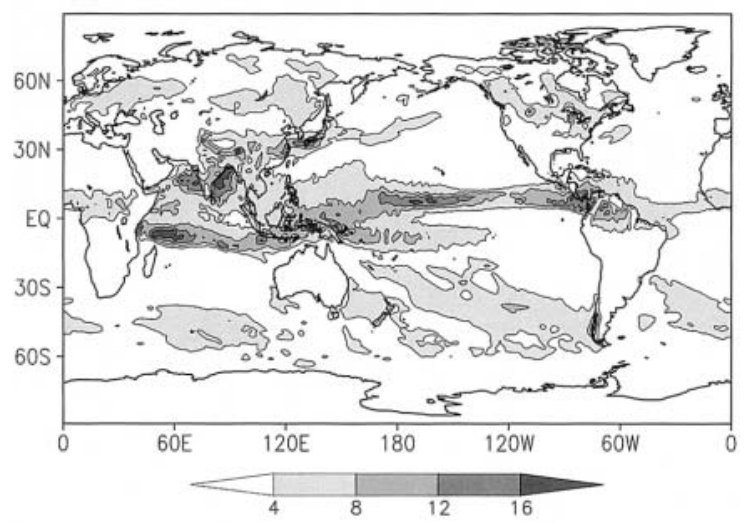

Fig. 1. The distributions of monthly mean precipitation in June. (a) Observation (Xie-Arkin) and (b) model $\left(\mathrm{mm} \mathrm{day}{ }^{-1}\right)$. The contour interval is 4 $\left(\mathrm{mm} \mathrm{day}{ }^{-1}\right)$ and values more than 4 $\left(\mathrm{mm} \mathrm{day}{ }^{-1}\right)$ are shaded.

is clearly seen. However, there is unrealistically large precipitation over the Indian Ocean around $10^{\circ} \mathrm{S}$.

The monthly averaged wind velocity fields at $850 \mathrm{hPa}$ and $200 \mathrm{hPa}$ in June are shown in Figs. $2 \mathrm{a}$ and $2 \mathrm{~b}$, respectively. Note that the number of vectors is reduced by a half along each longitude and latitude for clarity. At $850 \mathrm{hPa}$, the monsoon westerly and the circulation around the North Pacific subtropical anticyclone are predominant, and the monsoon trough is formed over the South of China. In the region, the monsoon westerly comes across the southeasterly around the western rim of the North Pacific subtropical-anticyclone. These winds are transformed to southwesterly 


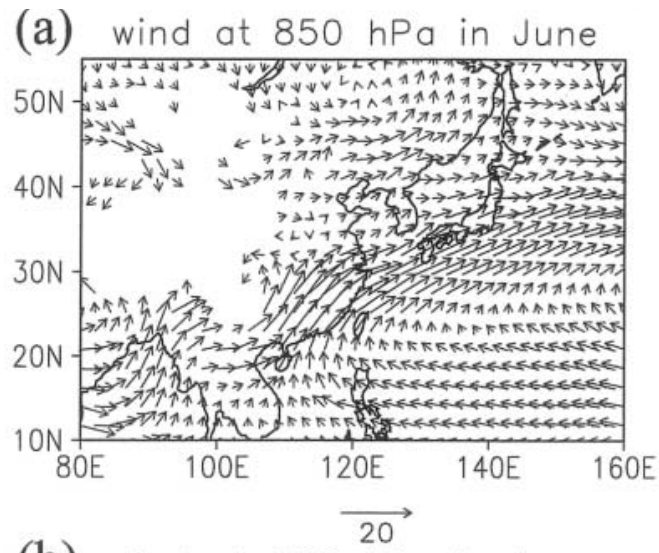

(b) wind at $200 \mathrm{hPa}$ in June

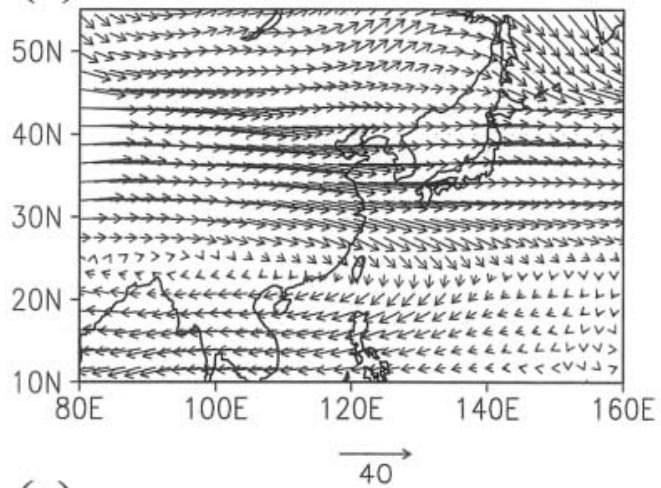

(c) Vapor Flux and DIV of V.F

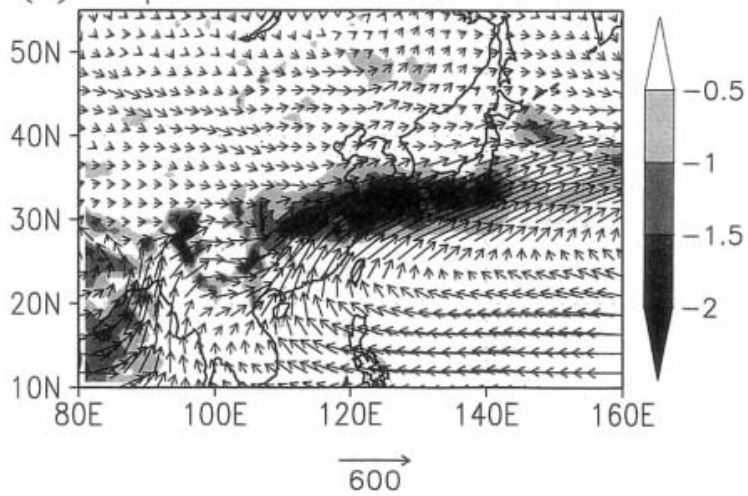

Fig. 2. (a) Monthly-averaged fields of wind velocity at (a) $850 \mathrm{hPa}$, (b) 200 $\mathrm{hPa}$ and (c) water vapor flux and its divergence integrated from surface to top in June. The arrow unit is $20\left(\mathrm{~ms}^{-1}\right)$ for (a), $40\left(\mathrm{~ms}^{-1}\right)$ for (b) and $600\left(\mathrm{~m}^{2} \mathrm{~s}^{-1}\right)$. Values less than $-0.5 \times 10^{-4}\left(\mathrm{~ms}^{-1}\right)$ are shaded for (c).

and intensified along the northwestern rim of the subtropical-anticyclone. This strong southwesterly is identified as the low-level jet

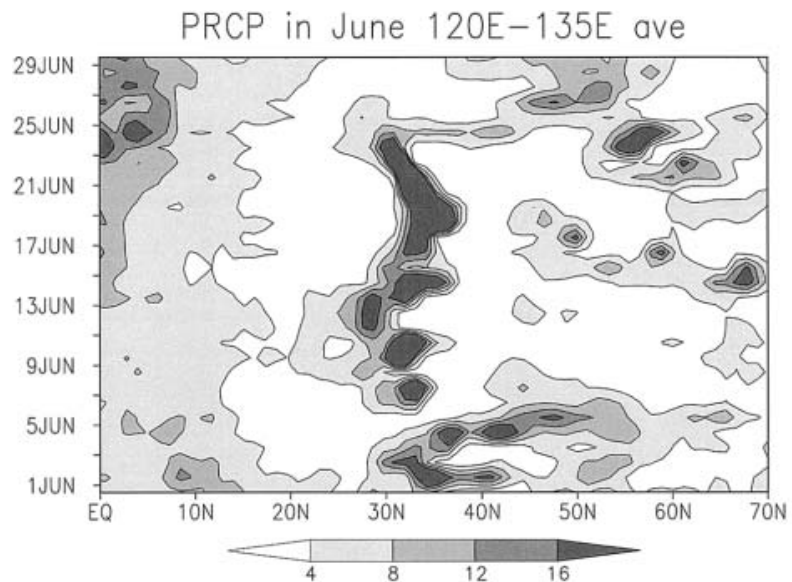

Fig. 3. Latitude-time cross sections of precipitation averaged from $120^{\circ} \mathrm{E}$ to $135^{\circ} \mathrm{E}$ during June. The contour interval is $4\left(\mathrm{~mm} \mathrm{day}^{-1}\right)$. Values more than 4 $\left(\mathrm{mm} \mathrm{day}{ }^{-1}\right)$ are shaded.

stream, and extends along the southern side of the Baiu front. Convergence of flow is formed around the Baiu front. At $200 \mathrm{hPa}$, the main axis of the Tibetan anticyclone lies along $25^{\circ} \mathrm{N}$. The position and strength of the subtropical jet over the Baiu front are around $35^{\circ} \mathrm{N}$ and about $35 \mathrm{~ms}^{-1}$, respectively. These features are comparable to the observations. Fig. $2 \mathrm{c}$ shows the water vapor flux and the convergence of water vapor flux integrated from the surface to the top level of the model. The Indian monsoon westerly and circulation around the subtropical-anticyclone transport moisture to the frontal zone. The width of the large convergence zone is $\sim 500 \mathrm{~km}$, which can be resolved in this simulation by $4-5$ grid points.

It is confirmed that the features of the monthly averaged fields and large-scale circulation in the model are similar to those of the real atmosphere (cf., Akiyama 1973).

\section{The structures of the Baiu front in the model}

In this section, the characteristic features of the Baiu front simulated in this experiment are investigated, and the model results are compared with observational results.

Figure 3 shows a latitude-time cross section of the precipitation during June averaged from $120^{\circ} \mathrm{E}$ to $135^{\circ} \mathrm{E}$. The data interval is 1 


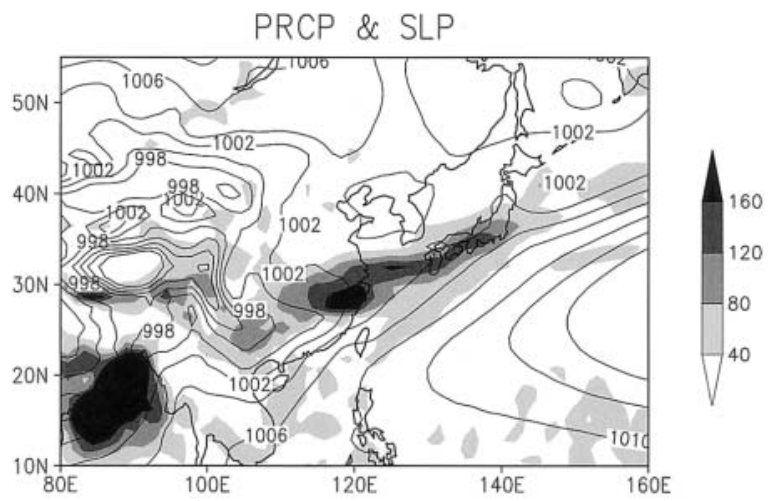

Fig. 4. The weekly-averaged distribution of precipitation $\left(\mathrm{mm}\right.$ week $\left.^{-1}\right)$ and Sea Level Pressure $(\mathrm{hPa})$. The contour interval is $40\left(\mathrm{~mm} \mathrm{week}^{-1}\right)$ for precipitation and $2(\mathrm{hPa})$ for SLP. Values more than $40\left(\mathrm{~mm} \mathrm{week}^{-1}\right)$ are shaded for precipitation.

day. Broad rainfall is shown in the equatorial region. The precipitation at high latitudes is formed by synoptic scale depressions as seen from daily data (figure not shown). A strong and sustained rainfall is observed around $32^{\circ} \mathrm{N}$ for most of the month. We examined the structures of the Baiu front for a week (June 10June 16) when activities of the front are typical and intense. Figure 4 shows the weekly averaged distribution of the precipitation and sealevel pressure (SLP). The low-pressure area is widely spread over the continent. The North Pacific subtropical-anticyclone protrudes westward, and a narrow rainfall zone is formed over the northwestern rim of the anticyclone. The maximum precipitation near the Baiu front is seen in the region of the Yangtze River.

Figures 5a, 5b and 5c show weekly-averaged fields of the geopotential height at $500 \mathrm{hPa}$, surface air temperature, and specific humidity at $500 \mathrm{hPa}$, respectively. In Fig. 5a, the low geopotential heights protrude from the Sea of Okhotsk to the north of the Baiu front, and strong curvature is seen. The contour lines of geopotential height are nearly straight around the front. The westward-extending subtropical anticyclone is also seen in this figure. Such conditions are important to simulate the Baiu front and are discussed in detail in section 6 . Blocking ridges and cut-off lows at high latitude are not clearly seen due to the weekly-
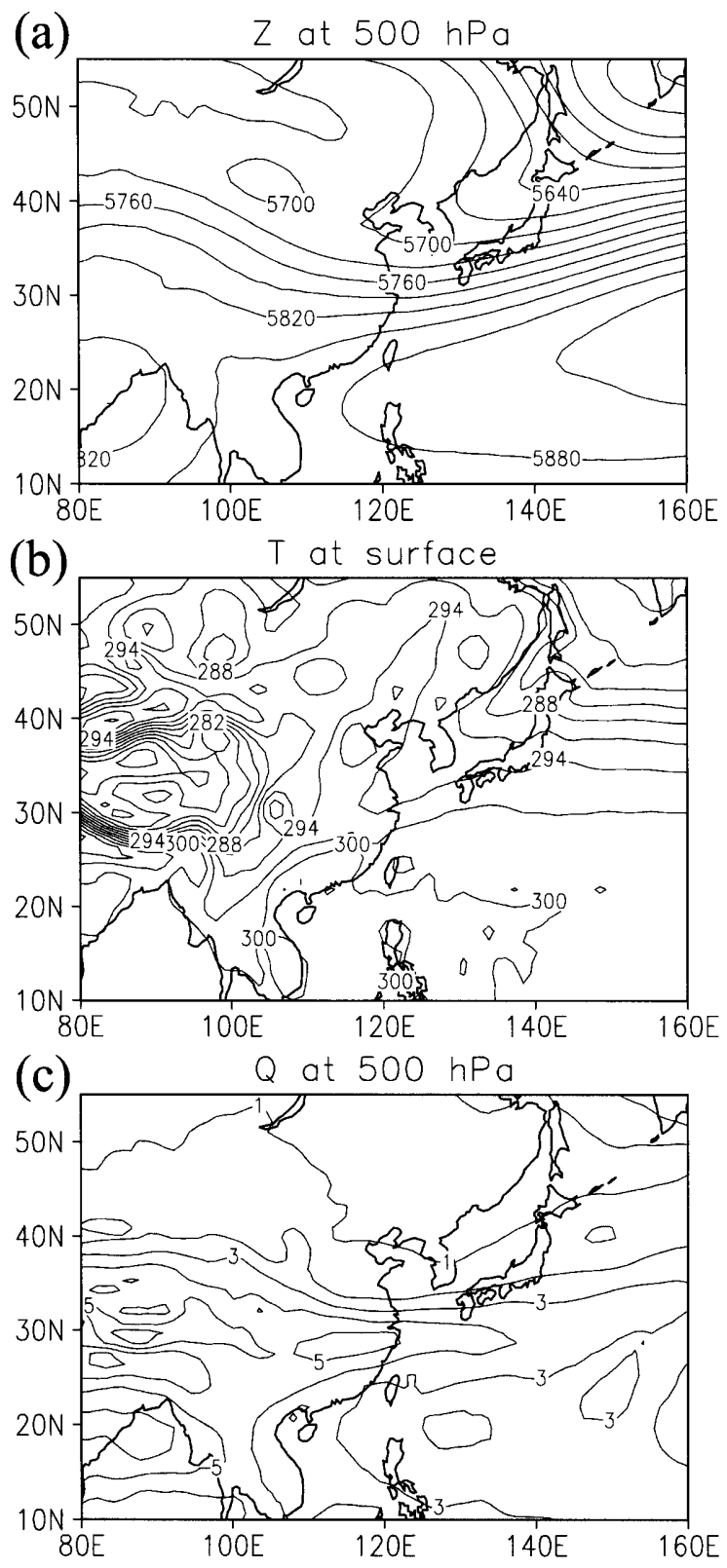

Fig. 5. The weekly-averaged (a) geopotential height $(\mathrm{m})$ at $500 \mathrm{hPa}$, (b) air surface temperature $(\mathrm{K})$ and (c) specific humidity at $500 \mathrm{hPa}\left(\mathrm{g} \mathrm{kg}^{-1}\right)$. The contour interval is $30(\mathrm{~m})$ for $(\mathrm{a}), 3(\mathrm{~K})$ for (b) and $1\left(\mathrm{~g} \mathrm{~kg}^{-1}\right)$ for (c).

averaged field. However, they are formed and move eastward as seen in snap shots (figure not shown). In Fig. 5b, a region of low temperature extends from the Kamchatka Peninsula toward 

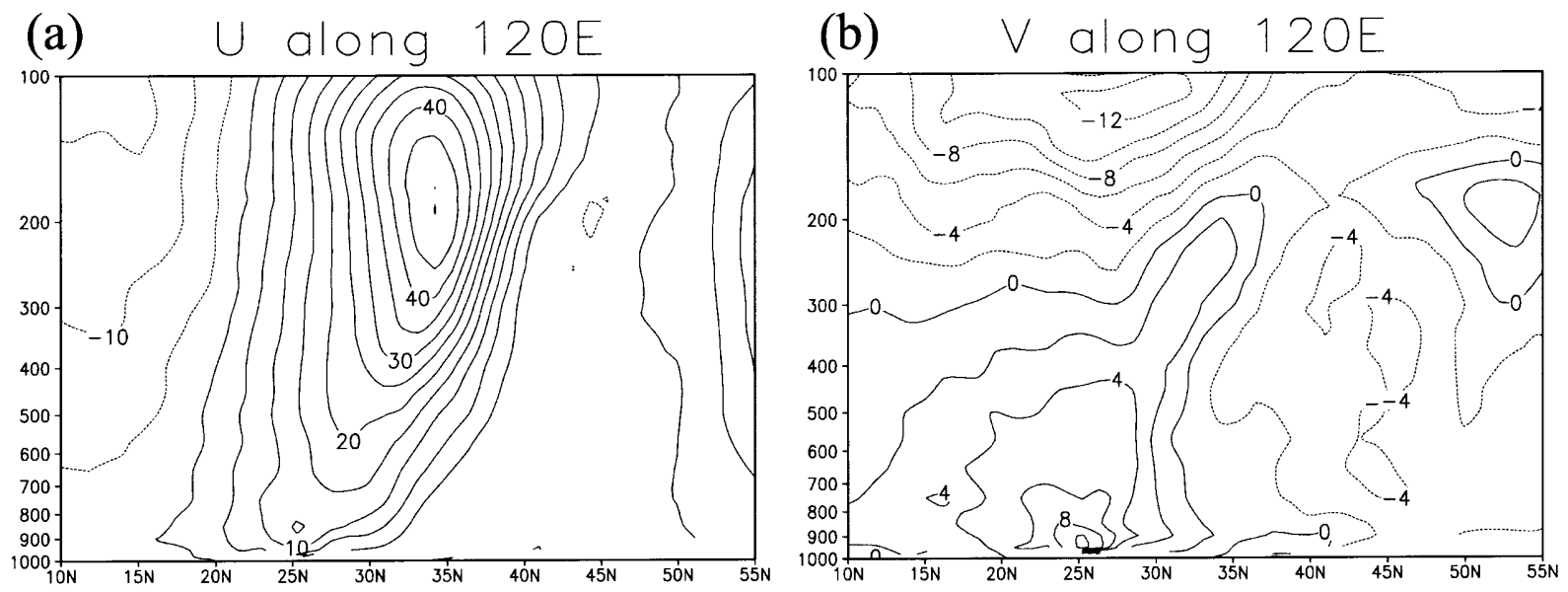

(c) OMG along 12OE
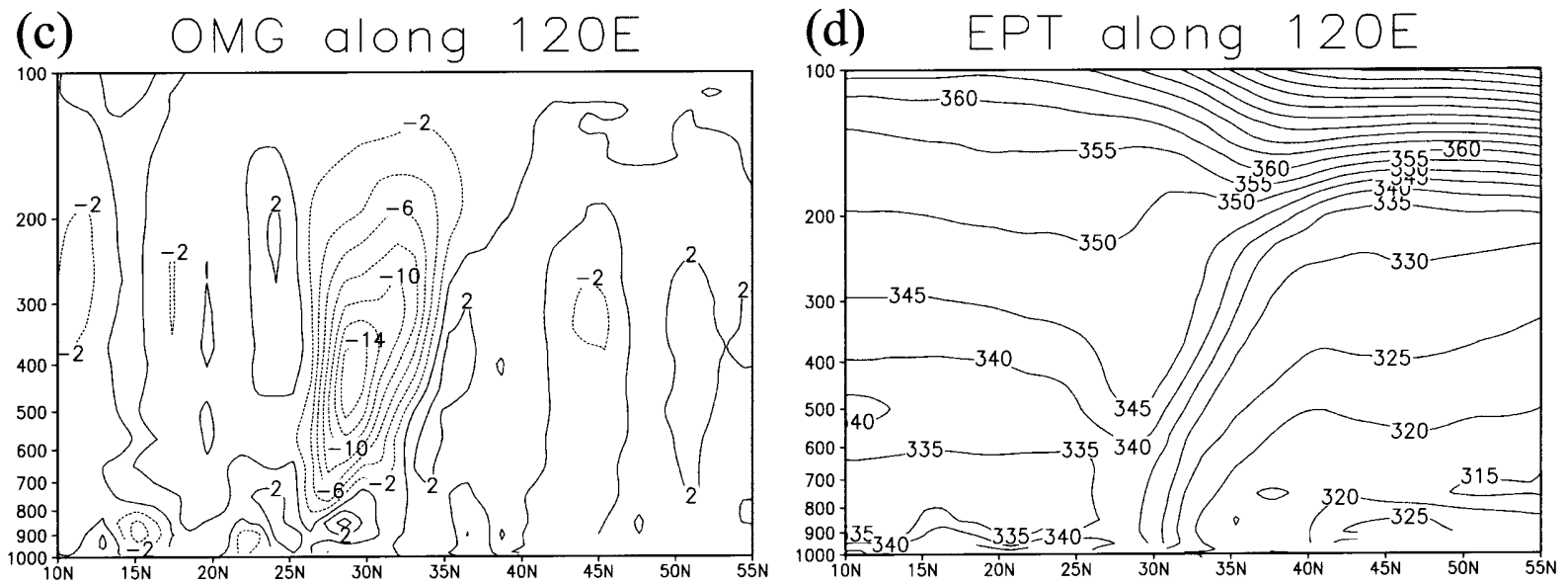

Fig. 6. The weekly-averaged latitude-height cross sections of (a) zonal wind ( $\mathrm{ms}^{-1}$ ), (b) meridional wind $\left(\mathrm{ms}^{-1}\right)$, (c) vertical p-velocity $\left(\mathrm{hPa}\right.$ hour ${ }^{-1}$ ) and (d) equivalent potential temperature $(\mathrm{K})$ along $120^{\circ} \mathrm{E}$. The contour interval is $5\left(\mathrm{~ms}^{-1}\right)$ for $(\mathrm{a}), 2\left(\mathrm{~ms}^{-1}\right)$ for $(\mathrm{b}), 2\left(\mathrm{hPa} h o u r^{-1}\right)$ for $(\mathrm{c})$ and $5(\mathrm{~K})$ for (d).

the Yangtze River. A relatively weak meridional thermal gradient is seen upstream of the Baiu front, while there is a relatively strong meridional gradient downstream of the front. A large longitudinal continent-ocean thermal contrast is seen to the north of the front. In Fig. $5 c$, an area of high specific humidity, a so-called 'moist tongue', protrudes from China toward the South of Japan. Matsumoto et al. (1971) pointed out that active cumulus convection makes this moist tongue. Strong upward motion is formed around the moist tongue in this simulation (figure not shown), consistent with Matsumoto et al. (1971). A large meridional gradient in mixing ratio is also seen around the Baiu front.
Further, we examined the meridionalvertical structure of the Baiu front. A longitude of $120^{\circ} \mathrm{E}$ is selected, where the maximum precipitation in the Baiu front occurs (see Fig. 4). Figures 6a-6d show weekly-averaged latitudeheight cross sections of zonal wind, meridional wind, vertical velocity in pressure-coordinates ( $p$-velocity), and equivalent potential temperature along $120^{\circ} \mathrm{E}$, respectively. A low level jet stream is formed around $700 \mathrm{hPa}, 27^{\circ} \mathrm{N}$ with a maximum magnitude of $15 \mathrm{~ms}^{-1}$ (Fig. 6a). The axis of the strong zonal wind tilts northward with height. The subtropical jet stream is seen around $200 \mathrm{hPa}, 34^{\circ} \mathrm{N}$. The largest southerly wind with magnitude $10 \mathrm{~ms}^{-1}$ is seen in the lower troposphere located south of the Baiu 
front (Fig. 6b), while the northerly wind appears to the north of the front. In the upper troposphere, the northerly wind associated with the Tibetan anticyclone reaches $12 \mathrm{~ms}^{-1}$. In Fig. 6c, large negative velocity (ascending motion) is confirmed around the Baiu front. The maximum upward motion reaches $14 \mathrm{hPa}$ hour $^{-1}$ around $450 \mathrm{hPa}$. On the other hand, downward motion appears on both sides of the front. The moist near-neutral stratification extends from the surface to about $600 \mathrm{hPa}$ within the heavy rainfall zone (Fig. $6 \mathrm{~d}$ ). In addition, high equivalent potential temperature in the lower layer and relatively low equivalent potential temperature in the middle layer are also confirmed south of the front. This indicates that a convectively unstable layer is formed there. On the other hand, relatively stable stratification is seen to the north of the front.

This experiment satisfactorily simulated the strengths of the low-level jet, the southerly wind to the south of the Baiu front in the lower troposphere, the northerly wind in the upper troposphere over the front, and upward motion within the active rainfall zone. These results are in good agreement with the real atmosphere (cf., Ninomiya 2000). In the next section, the meso- $\alpha$-scale circulation systems in the model are discussed.

\section{Meso- $a$-scale disturbances appearing in the model}

Although the Baiu front looks like a quasiequilibrium feature, it involves several meso$\alpha$-scale disturbances. Several workers have pointed out that these disturbances are important for the formation of the front (Akiyama 1984 and 1989; Ninomiya and Akiyama 1992). It is accepted that the Baiu front can be considered as a chain of meso- $\alpha$-scale disturbances which develop during eastward movement. In the present paper, the generation of such disturbances and the relationship between disturbances and precipitation in the model are examined. To investigate them explicitly, output intervals of 1 hour are used for the duration of a week.

Figures $7 \mathrm{a}$ and $7 \mathrm{~b}$ show the longitude-time cross sections of relative vorticity at 850 $\mathrm{hPa}$ and precipitation along $31^{\circ} \mathrm{N}$, respectively. The meso- $\alpha$-scale disturbances are generated around $115^{\circ} \mathrm{E}$, and an eastward propagation is
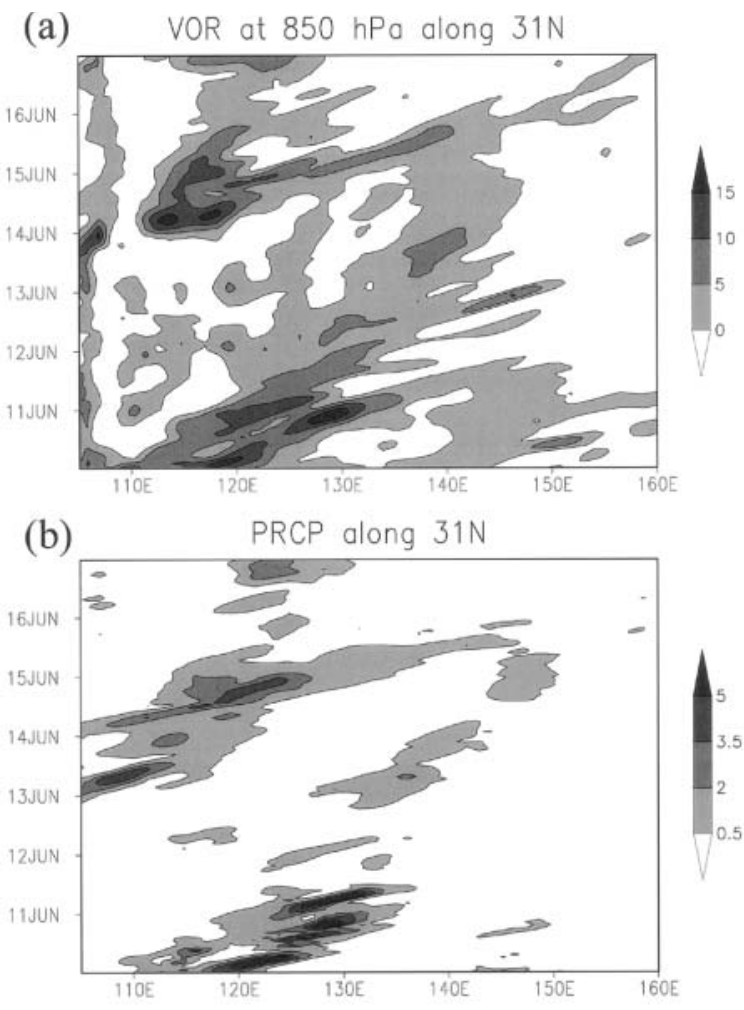

Fig. 7. The longitude-time cross sections of (a) vorticity at $850 \mathrm{hPa}$ and (b) precipitation along $31^{\circ} \mathrm{N}$. The contour interval is $5 \times 10^{-5}\left(\mathrm{~s}^{-1}\right)$ and positive values are shaded for (a). The contour interval is 1.5 (mm hour $^{-1}$ ) and values more than $0.5\left(\mathrm{~mm} \mathrm{hour}^{-1}\right)$ are shaded for (b).

clearly seen, with a speed of about $1000 \mathrm{~km}$ $\mathrm{day}^{-1}$. It is also noted that these meso- $\alpha$-scale circulations have a strong correlation with precipitation. Ninomiya and Akiyama (1971), and Yoshizumi (1977) reported that the disturbances in the frontal zone tilt eastward with height in a vorticity field. These disturbances are confined up to $400 \mathrm{hPa}$. Similar eastward tilting structures are found (not shown) around continental China where the baroclinicity is found to be weak (see Fig. 5b). A more detailed analysis is needed to examine why such structures are formed.

Figures $8 \mathrm{a}$ and $8 \mathrm{~b}$ show the standard deviation of the wind velocity at $850 \mathrm{hPa}$ and that of the vertical p-velocity at $500 \mathrm{hPa}$ over time. The large value of the standard deviation 
(a) STD of wind at $850 \mathrm{hPa}$

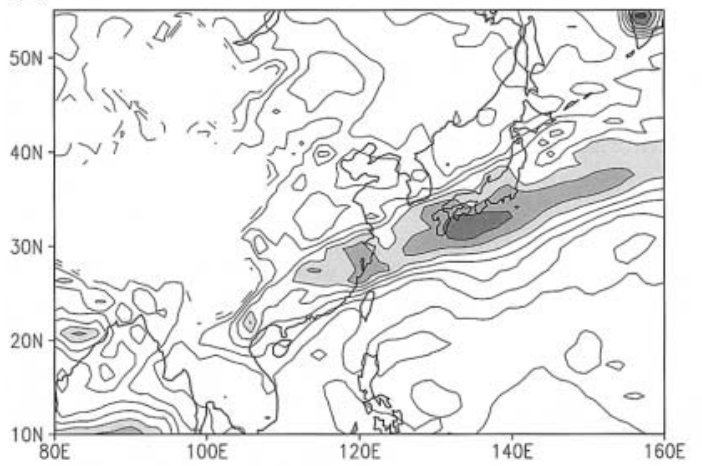

(b) STD of OMG at $500 \mathrm{hPa}$

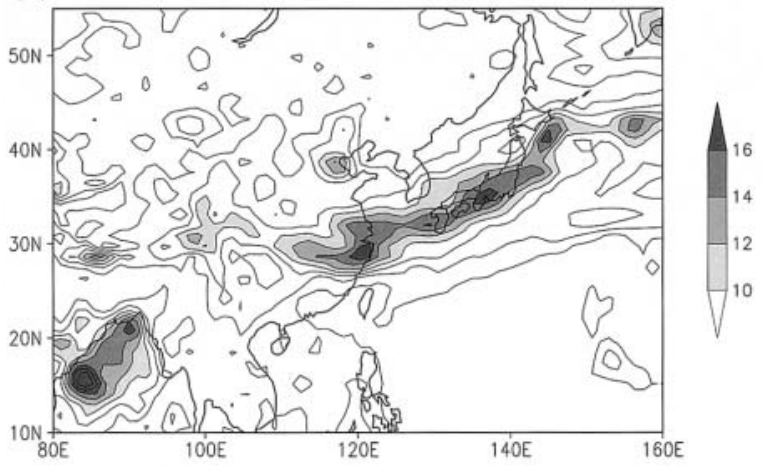

Fig. 8. The standard deviation of (a) wind velocity at $850 \mathrm{hPa}\left(\mathrm{ms}^{-1}\right)$ and (b) vertical $\mathrm{p}$-velocity $\left(\mathrm{hPa}\right.$ hour $\left.^{-1}\right)$ at 500 $\mathrm{hPa}$ over time. The contour interval is 1 $\left(\mathrm{ms}^{-1}\right)$ and values more than $6\left(\mathrm{~ms}^{-1}\right)$ are shaded for (a). The contour interval is $2\left(\mathrm{hPa} \mathrm{hour}^{-1}\right)$ and values more than $10\left(\mathrm{hPa} \mathrm{hour}^{-1}\right)$ are shaded for (b).

suggests that time-varying disturbances have large amplitudes. These figures are related to the activities of meso- $\alpha$-scale disturbances. The large values of the standard deviation of wind velocity and vertical p-velocity are aligned along the Baiu front. In general, the standard deviation of the horizontal velocity and the vertical p-velocity increase down stream of the Baiu front. This indicates that the disturbances develop during eastward propagation. A strong upward motion is formed in the southern part of China (not shown), and disturbances are generated over the region (see Fig. 7a). To summarize, some of the meso- $\alpha$-scale disturbances generated in the southern part of China move eastward and develop along the frontal zone. Our results strongly support those re-

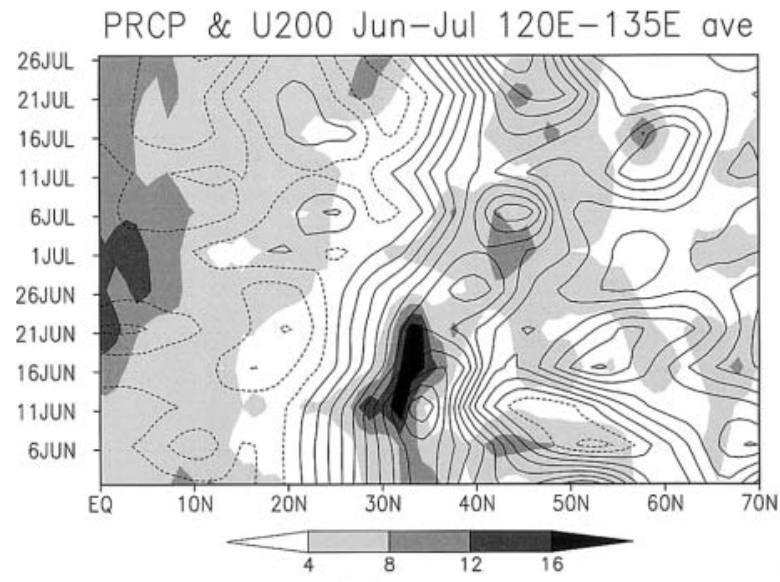

Fig. 9. Latitude-time cross-sections of zonal wind at $200 \mathrm{hPa}$ and precipitation averaged from $120^{\circ} \mathrm{E}$ to $135^{\circ} \mathrm{E}$. The contour interval is $5\left(\mathrm{~ms}^{-1}\right)$ for zonal wind, $4\left(\mathrm{~mm}\right.$ day $\left.^{-1}\right)$ for precipitation and values more than $4\left(\mathrm{~mm} \mathrm{day}^{-1}\right)$ are shaded for precipitation.

ported in a recent study by Ninomiya (2000) using reanalysis data.

\section{Discussions on simulation of the Baiu front in an AGCM}

\subsection{The Baiu front in July}

It is well-known that the Baiu front is formed in the southern part of Japan around the end of May, and that it gradually shifts northward and disappears by the end of July in the climatology. In an early study, Murakami (1951) showed by analyzing upper air observational data that the subtropical jet over Japan disappears when the Baiu front no longer exists. Yoshikane et al. (2001) reported that the location of the Baiu front is quite sensitive to the zonal mean field utilized as a boundary condition in their regional model experiments. In another study, utilizing NCEP/NCAR reanalysis data and model simulation, results showed that the Baiu front disappears if the subtropical jet moves northward (Suzuki 2001).

In the experiment at T106L60, the Baiu front is well simulated during June. However, a similar precipitation field is not seen during July, though the Baiu front also appears in July in the real atmosphere. Figure 9 shows the latitude-time cross section of zonal wind (contours) at $200 \mathrm{hPa}$ and precipitation (shaded) in the 

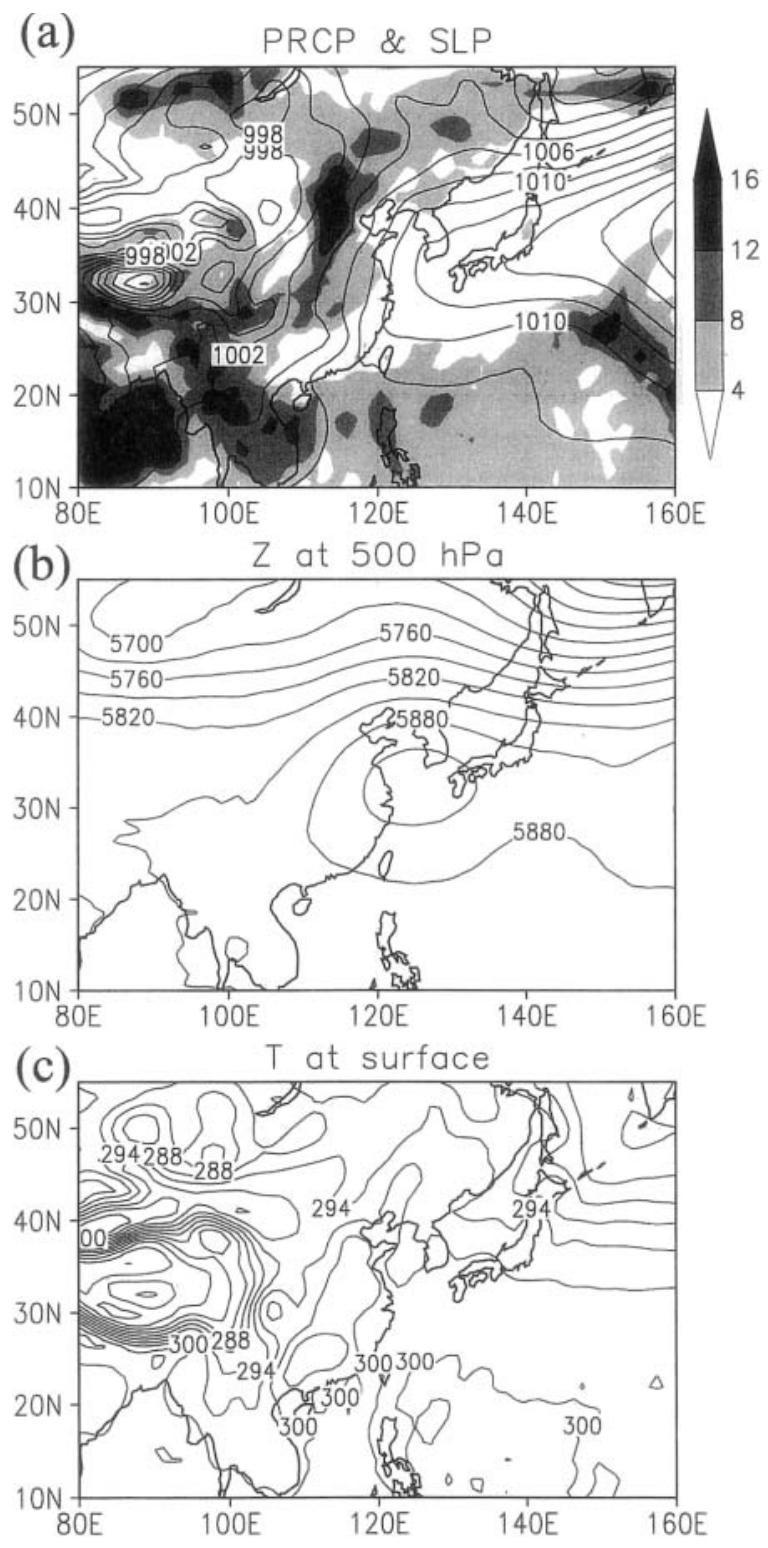

Fig. 10. The weekly-averaged (a) precipitation $\left(\mathrm{mm} \mathrm{day}{ }^{-1}\right.$ ) and SLP (hPa), (b) geopotential height $(\mathrm{m})$ at $500 \mathrm{hPa}$, and (c) air surface temperature (K). The contour interval is $4\left(\mathrm{~mm} \mathrm{day}{ }^{-1}\right)$ for precipitation and $2(\mathrm{hPa})$ for SLP for (a), $30(\mathrm{~m})$ for $(\mathrm{b})$, and $3(\mathrm{~K})$ for $(\mathrm{c})$. Values more than $4\left(\mathrm{~mm} \mathrm{day}{ }^{-1}\right)$ are shaded for (a).

model from June through July averaged from $120^{\circ} \mathrm{E}$ to $135^{\circ} \mathrm{E}$. The data interval is 5 days. The position and strength of the subtropical jet is around $35^{\circ} \mathrm{N}$ and $40 \mathrm{~ms}^{-1}$ on the first of June. A rainfall zone is formed just to the south of the subtropical jet through June. However, this rainfall zone suddenly disappears near the end of June, when the subtropical jet associated with weak winds shifts toward $\sim 40^{\circ} \mathrm{N}$.

Figure 10a shows the distributions of precipitation and SLP averaged from 10 to 16 July, when a weak subtropical jet is located to the north of Japan. The North Pacific subtropicalanticyclone protrudes northwestward, and covers the whole of the Islands of Japan. A rainfall zone is formed on the northwestern rim of the subtropical high. Figures $10 \mathrm{~b}$ and 10c show the distributions of geopotential height at $500 \mathrm{hPa}$ and surface air temperature, respectively. In Fig. 10b, the trough from highlatitudes to mid-latitudes is weak. The cut-off low and blocking ridge are not clearly seen at high-latitudes as they are in the daily data (figure not shown). The position of the subtropical-anticyclone is further north, and it protrudes up to continental China. These features are quite different from those in the period when the Baiu front appears. In Fig. 10c, the high-latitude trough does not extend as far as China. The temperature over the southern part of China is higher than in the observations. These structures are seen through July (not shown), and as a result, the Baiu front could not be simulated in July.

\subsection{Resolution dependence of the Baiu front}

In order to examine the resolution dependence for simulation of the Baiu front, a few experiments are conducted and the results are discussed in this section. Figures 11a, 11b and 11c show the distributions of precipitation during June at horizontal resolutions of T21, T42 and T106, respectively. Note here that the models have the same 20 layers in the vertical, and that the top boundary is at about $30 \mathrm{~km}$. The experiments at T21 and T42 are done under the standard setting of the CCSR/NIES AGCM (cf., Numaguti et al. 1997), although a strong value for the drag in the gravity wave parameterization is used as for the T106 experiment (cf., Kawatani and Takahashi 2000). These figures show two-year-averaged fields. It is obvious that the global distribution of precipitation is better using higher resolution. For example, the formation of the ITCZ and the 


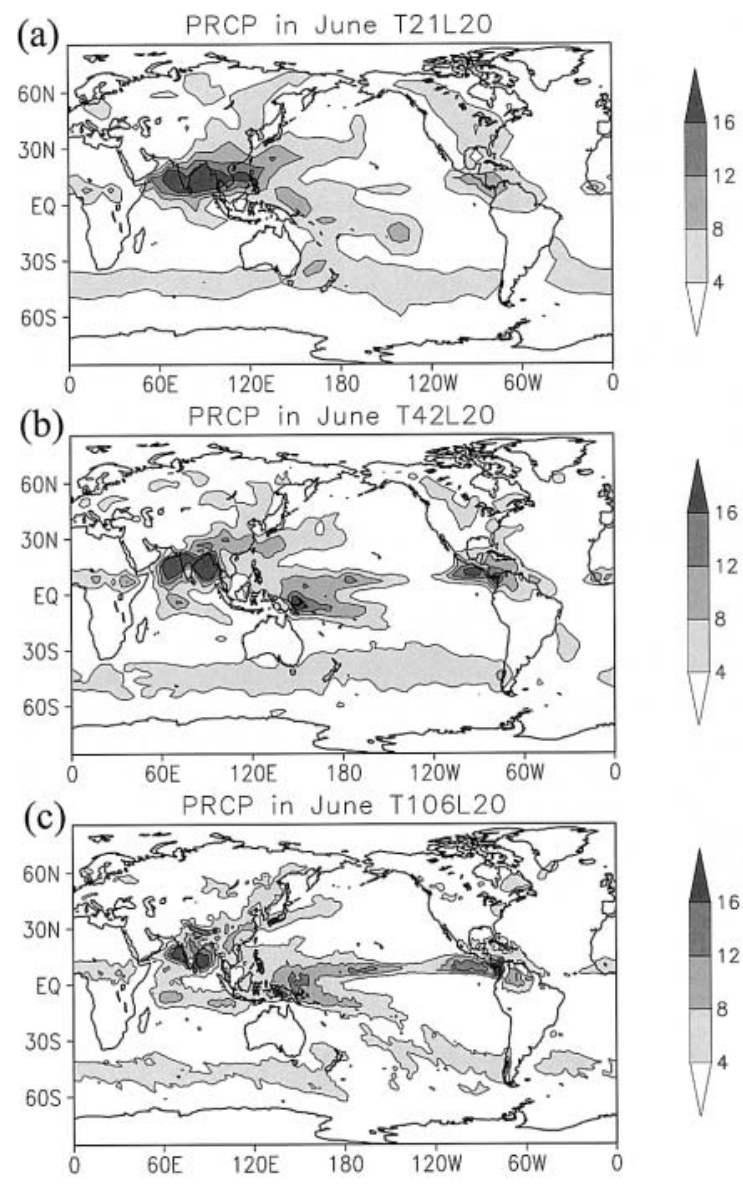

Fig. 11. The distributions of monthly mean precipitation in June. (a) T21L20, (b) T42L20 and (c) T106L20 (mm day ${ }^{-1}$ ). The contour interval is $4\left(\mathrm{~mm} \mathrm{day}^{-1}\right)$ and values more than $4\left(\mathrm{~mm} \mathrm{day}^{-1}\right)$ are shaded.

separation between the ITCZ and SPCZ are better than those at coarse resolution. The patterns of light precipitation in the tropical western part of the Pacific Ocean are also in good agreement with the observations as the resolution increases. Such features are important for the simulation of the Baiu front (cf., Emori et al. 2001). The Baiu-like frontal zone appears in the results of the T106L20 experiment.

Large-scale circulations, as shown in section 3 , can be simulated by using lower resolution, and a Baiu-like frontal zone sometimes appears in the daily data. But the width of the large convergence zone of water vapor is $\sim 500 \mathrm{~km}$ in the real atmosphere. In addition, the charac- teristics of the Baiu front mentioned in section 4 are several hundreds of kilometers in scale. In the lower resolution experiments, the strength of the low-level jet, southerly inflow toward the Baiu front in the lower troposphere, vertical p-velocity within the active rainfall zone, and northerly wind over the front in the upper troposphere are weaker than those in the observations (cf., Ninomiya et al. 2001, 2002). Lower resolutions may be too coarse to represent such features sufficiently. Using the high resolution model, the $\sim 500 \mathrm{~km}$ large convergence zone is well simulated (see Fig. 2c), and the magnitudes of the wind fields around the Baiu front are greatly improved (see Fig. 6).

The drag of the mountain gravity wave parameterization (cf., McFarlane 1987) is set stronger in the experiment at T106L20 as mentioned above. If we use the standard value of the drag (cf., Numaguti et al. 1997), the subtropical jet is about $10 \mathrm{~ms}^{-1}$ stronger upstream of the Baiu front than that in the simulation with stronger gravity wave drag. The meridional gradients of temperature around the Baiu front are enhanced, although the Baiu front is characterized by weak baroclinicity (cf., Peng and Tsuboki 1997).

When the number of vertical layer is increased, the gravity wave features are more explicit. The clarity of resolved gravity wave drag is also improved. Although a large value is used for the gravity wave drag parameterization in the experiment at T106L20, it is not needed for such a large drag at T106L60. The gravity wave drag parameterization is not used in the experiment at T106L60, as the strength of the subtropical jet is similar to the observations as shown (see Fig. 9). When a high horizontal resolution is used, it is also necessary to have a greater number of layers in the vertical (Lindzen and Fox-Rabinovitz 1989: see also Sato et al. 1999) for dynamical consistency. Therefore, a resolution of T106L60 is used in this experiment.

\subsection{Cumulus parameterization dependence of the Baiu front}

Finally, the dependence of the simulation of the Baiu front on the cumulus parameterization scheme is examined. The AGCM can not resolve the scales of convective process, so a cumulus parameterization is required. Al- 
(a)

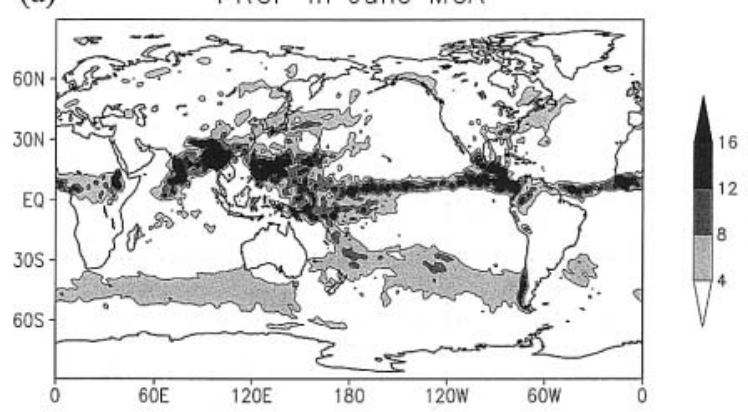

(b) V.F. \& DIV of V.F. in June MCA

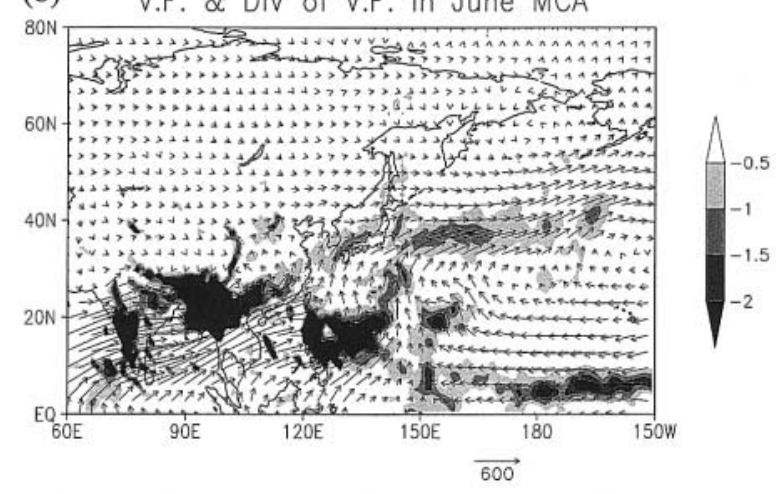

Fig. 12. (a) The distribution of precipitation and (b) water vapor flux and its integration from surface to top by using MCA parameterization. The contour interval is $4\left(\mathrm{~mm} \mathrm{day}^{-1}\right)$ and values more than $4\left(\mathrm{~mm} \mathrm{day}^{-1}\right)$ for (a) and less than $-0.5 \times 10^{-4}\left(\mathrm{~ms}^{-1}\right)$ for (b) are shaded. The arrow unit is $600\left(\mathrm{~m}^{2} \mathrm{~s}^{-1}\right)$ for $(\mathrm{b})$.

though several kinds of cumulus parameterization exist, the moist convective adjustment (MCA) scheme (based on Manabe and Strickler 1964), and the Kuo scheme (based on Kuo 1974) are chosen in order to examine the effects of cumulus parameterization, using the same T106L20 resolution. The MCA scheme applies instantaneous adjustment by convection if the layer is unstable. The Kuo scheme correlates convection to the amount of grid-scale moisture convergence.

Figure 12a shows the two-year-averaged global distribution of precipitation during June using the MCA scheme. The global distribution of precipitation is simulated qualitatively compared to the observations (see Fig. 1a). The equatorial region experiences heavier rainfall than seen in the observations, and the separa-
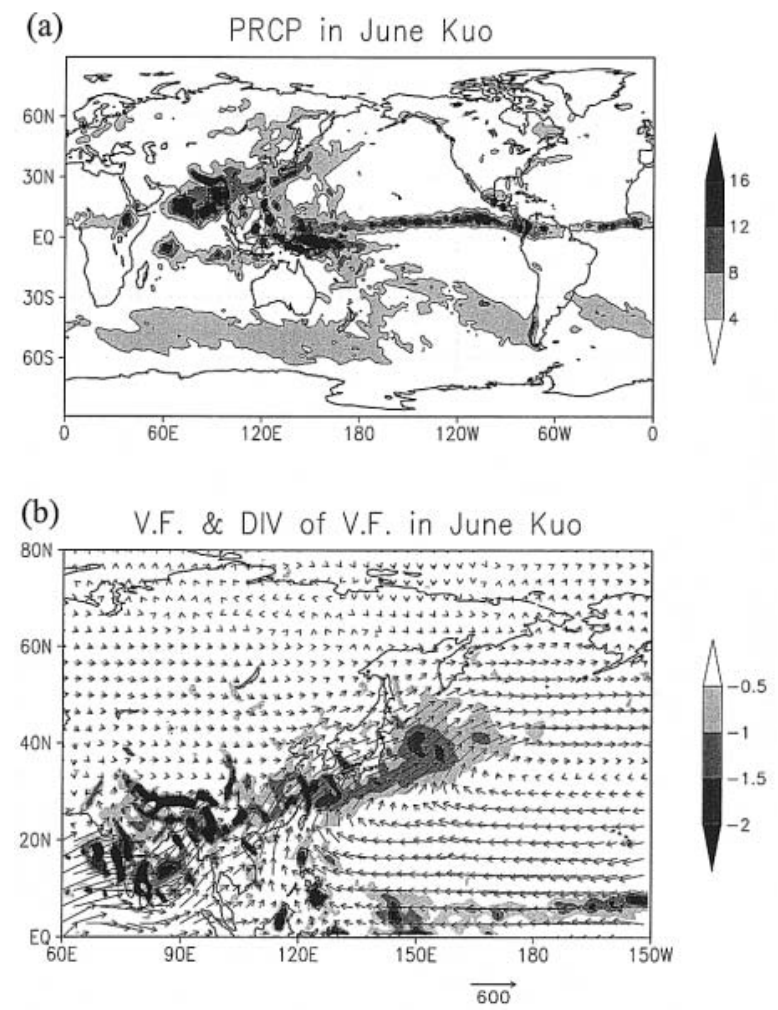

Fig. 13. The same figures as Fig. 12 but using the Kuo scheme.

tion between the ITCZ and the SPCZ is weak. There is also heavy rainfall around the Bay of Bengal and over the western Pacific near the Philippines, while the amount of precipitation is much less over the Indonesian region. Figure $12 \mathrm{~b}$ shows the water vapor flux and its divergence integrated from the surface to the top level of the model around Japan. The North Pacific subtropical-anticyclone retreats eastward, and the Indian monsoon westerly penetrates to $140^{\circ} \mathrm{E}, 20^{\circ} \mathrm{N}$. As a result, heavy rainfall is formed around the Philippines, and low water vapor is obtained around Japan. Such features are unfavorable for formation of the Baiu front (Ninomiya 1984).

Figures 13a and 13b show the precipitation, the water vapor flux and its divergence using the Kuo scheme, respectively. The global distribution of precipitation is similar to the observations, although the amount of precipitation is greater in equatorial regions. The large-scale circulation satisfies the conditions favorable for the formation of the Baiu front, 

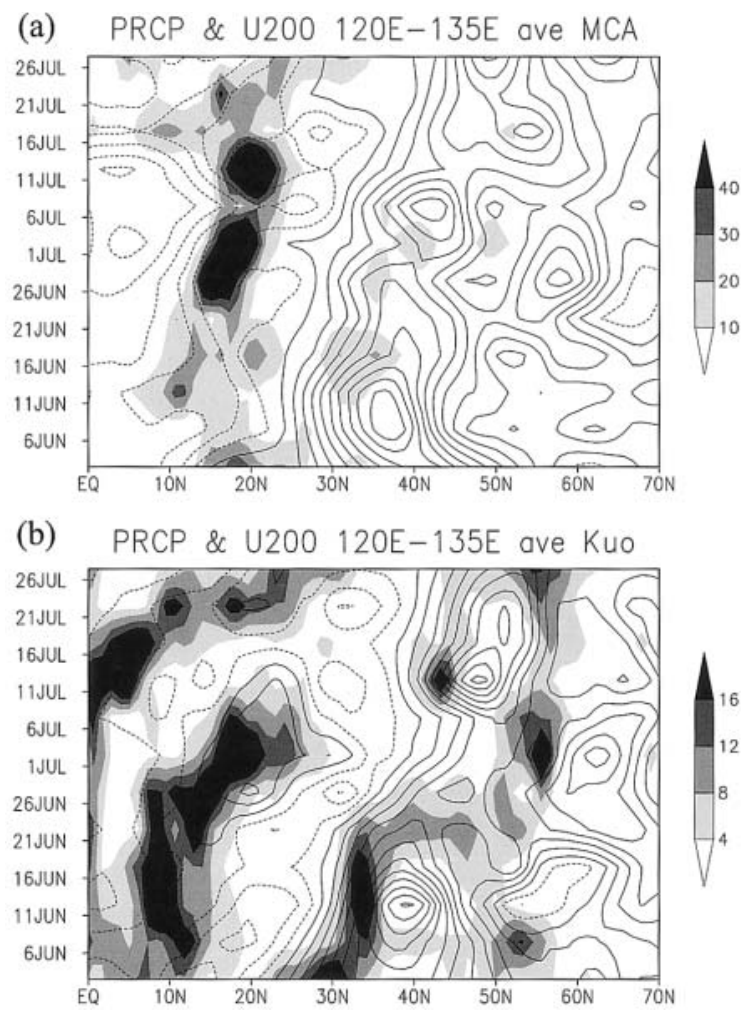

Fig. 14. The same as Fig. 9 but using the (a) MCA scheme and (b) Kuo scheme. Contour intervals of precipitation are $10\left(\mathrm{~mm} \mathrm{day}^{-1}\right)$ and values more than 10 $\left(\mathrm{mm} \mathrm{day}{ }^{-1}\right)$ is shaded for (a), and the same as Fig. 9 for (b). Contour intervals of zonal wind are $5\left(\mathrm{~ms}^{-1}\right)$ for both figures.

and a realistic zone of convergence of water vapor flux is formed south of Japan. As a result, the Baiu-like rainfall zone is relatively well simulated. The pattern of geopotential height at $500 \mathrm{hPa}$ (not shown) is similar to Fig. 5a.

Figures 14a and 14b show a latitude-time cross section of zonal wind (contours) at 200 $\mathrm{hPa}$, and precipitation (shaded) from June through July averaged from $120^{\circ} \mathrm{E}$ to $135^{\circ} \mathrm{E}$ for the MCA scheme and the Kuo scheme, respectively. The data interval is 5 days. These figures are the results of the first year of integration. Note that the shaded range of Fig. 14a is different from those in other figures (Fig. 9, Fig. 14b). In the MCA experiment, heavy rainfall occurres around $18^{\circ} \mathrm{N}$ with a maximum value of $\sim 90 \mathrm{~mm}$ day $^{-1}$. This feature is not realistic as indicated before. The Kuo experiment simulates a continuous rainfall zone around Japan until near the end of June. However, the earlier northward shift of the subtropical jet is found with both the parameterizations. Therefore, the Baiu-like rainfall zone did not appear in July, similar to the results obtained using the Arakawa-Schubert scheme (see Fig. 9).

Although there are possibilities of simulating the Baiu front in a more sophisticated way if parameterizations are improved, or using a suitable tuning parameter for high resolution GCMs, it is suggested that the pattern of the North Pacific subtropical anticyclone and the formation of subtropical precipitation are important (Ninomiya 1984 and Emori et al. 2001).

\section{Summary and concluding remarks}

Using a high resolution GCM (T106L60), the features of the Baiu front appearing in the model are examined. The horizontal resolution is about $110 \mathrm{~km}$, which provides several grid points to resolve the Baiu frontal zone. A high vertical resolution is also used to satisfy the consistency between horizontal and vertical resolution (Lindzen and Fox-Rabinovitz 1989).

The characteristics of the Baiu front from large-scale to meso- $\alpha$-scale are well simulated in this experiment. The large-scale circulations such as the monsoon westerly and circulation around the North Pacific anticyclone are well simulated. The characteristics of the simulated Baiu front, such as a strong meridional gradient of moisture and a moist neutral stratification, are also similar to the real atmosphere. The magnitude of the low-level jet, southerly inflow to the Baiu front in the lower troposphere, northerly over the front in the upper troposphere, and vertical p-velocity within the active rainfall zone are quite similar to observations (cf., Ninomiya 2000). On the other hand, these structures could not be simulated quantitatively in a lower resolution AGCM (cf., Ninomiya et al. 2001, 2002). Although the model can not resolve meso- $\beta$ or meso- $\gamma$-scale disturbances, which are connected with meso- $\alpha-$ scale disturbances, there are some similarities between features of meso- $\alpha$-scale disturbances in the model and those in the observations (Ninomiya 2000). The meso- $\alpha$-scale disturbances propagate eastward and develop along the Baiu 
front. There is a strong correlation between precipitation and these disturbances.

The Baiu front is simulated during June, but it can not be simulated during July. The subtropical anticyclone covers Japan, and the rainfall zone is formed further north. The magnitude of the temperature over China is higher than in observations. The pressure field and large-scale circulation system are not similar to the observations.

The global distribution of precipitation is improved by using a higher horizontal resolution as expected. The formation of the ITCZ, the separation between the ITCZ and SPCZ, and the patterns of small precipitation in the western part of the Pacific Ocean are in good agreement with observations, and are important for simulation of the Baiu front (cf., Emori et al. 2001). In the T106L20 experiment, the Baiulike frontal zone is formed by using a strong gravity wave drag parameterization. The strength of the subtropical jet over the Baiu front is important for a good simulation.

In the case of the MCA experiment, heavy rainfall is formed around the Philippines. The large-scale circulation is characterized by eastward retreat of the Pacific subtropicalanticyclone and penetration of the Indian monsoon westerly to around $140^{\circ} \mathrm{E}, 20^{\circ} \mathrm{N}$. These features are not favorable to the formation of the Baiu front (cf., Ninomiya 1984). As a result, the Baiu front is not simulated in the MCA case. On the other hand, the Baiu-like rainfall zone is simulated in the experiment with the Kuo scheme.

The earlier northward shift of the subtropical jet is seen in each cumulus parameterization experiment, so it may not depend much on cumulus parameterization. An adequate treatment of the large-scale circulation is needed to simulate the Baiu front.

\section{Acknowledgements}

We thank Dr. K. Ninomiya for several discussions, valuable suggestions and encouragement. We also thank Prof. A. Sumi, Prof. M. Kimoto and Dr. S. Emori for various suggestions. We express our gratitude to Prof. S.K. Dhaka and Dr. O. Wild for improving our English in the manuscript. We also express our thanks to Dr. K. Tsuboki and two anonymous reviewers for constructive comments on the original manuscript. The calculations were made on a HITACHI SR8000, Computer Center, University of Tokyo. GrADS was used for the drawings.

\section{References}

Akiyama, T., 1973: The large-scale aspects of the characteristic features of the Baiu front, Pap. Met. Geophys., 24, 157-188. , 1975: Southerly transversal moisture flux into the extremely heavy rainfall zone in the Baiu season, J. Meteor. Soc. Japan, 53, 304316.

1984: A medium scale cloud cluster in a Baiu front. Part I: Evolution process and fine structure, J. Meteor. Soc. Japan, 62, 485-504. , 1989: Large, synoptic and mesoscale variations of the Baiu front during July 1982. Part I: Cloud feature, J. Meteor. Soc. Japan, 67, 5781.

Arakawa, A. and W.H. Schubert, 1974: Interactions of cumulus cloud ensemble with the large-scale environment. Part I. J. Atmos. Sci., 46, 661685.

Emori, S., T. Nozawa, A. Numaguti and I. Uno, 2001: Importance of Cumulus Parameterization for Precipitation Simulation over East Asia in June, J. Meteor. Soc. Japan, 79, 939-947.

Kawatani, Y. and M. Takahashi, 2000: Baiu Front Appearing in a High-resolution GCM Simulation. Proceeding of The Second International Symposium on Asian Monsoon System, Cheju, Korea, 239-245.

Kuo, H.L., 1974: Further studies of the parameterization of the influence of cumulus convection on large-scale flow. J. Atmos. Sci., 31, 1232-1240.

Le Treut H. and Z.-X. Li, 1991: Sensitivity of an atmospheric general circulation model to prescribed SST changes: Feedback effects associated with the simulation of cloud optical properties, Clim. Dyn., 5, 175-187.

Lindzen, R.S. and M. Fox-Rabinovitz, 1989: Consistent vertical and horizontal resolution, Mon. Wea. Rev., 117, 2575-2583.

Manabe, S. and R. Strickler, 1964: Thermal equilibrium of the atmosphere with a convective adjustment. J. Atmos. Sci., 21, 361-385.

Matsumoto, S., K. Ninomiya and S. Yoshizaki, 1971: Characteristics of the Baiu front with heavy rainfall, J. Meteor. Soc. Japan, 49, 267-281.

McFarlane, N.A., 1987: The effect of orographically excited gravity wave drag on the general circulation of the lower stratosphere and troposphere, J. Atmos. Sci., 44, 1775-1800.

Mellor, G.L. and T. Yamada, 1982: Development of a turbulence closure model for planetary 
boundary layers, Rev. Geophys. Atmos. Phys., 20, 851-875.

Murakami, T., 1951: On the study of the change of the upper westerlies in the last stage of Baiu season (rainy season in Japan). J. Meteor. Soc. Japan, 29, 162-175.

Nakajima, T. and M. Tanaka, 1986: Matrix formulation for the transfer of solar radiation in a plane-parallel scattering atmosphere, $J$. Quant. Spectrosc. Radiat. Transfer, 35, 13-21.

Ninomiya, K., 1984: Characteristics of Baiu front as a predominant subtropical front in the summer Northern Hemisphere, J. Meteor. Soc. Japan, 62, 880-894.

, 1999: Moisture balance over China and the South China Sea during the summer Monsoon in 1991 in relation to the intense rainfalls over China, J. Meteor. Soc. Japan, 77, 737751.

, 2000: Large- and Meso- $\alpha$-scale Characteristics of Meiyu/Baiu Front Associated with Intense Rainfalls in 1-10 July 1991, J. Meteor. Soc. Japan, 78, 141-157.

and T. Akiyama, 1971: The Development of the Medium-scale Disturbance in the Baiu front. J. Meteor. Soc. Japan, 49, 663-677.

- and - 1992: Multi-scale features of Baiu, the summer monsoon over Japan and the East Asia, J. Meteor. Soc. Japan, 70, 467495.

and T. Murakami, 1987: The early summer rainy season (Baiu) over Japan. Monsoon $\mathrm{Me}$ teorology. Edit. Chang, P.-C. and T.N. Krishnamurti, Oxford Univ. Press, 93-121.

and H. Muraki, 1986: Large-scale circulation over the East Asia during Baiu period of 1979, J. Meteor. Soc. Japan, 64, 409-429.

, T. Nishimura, W. Ofuchi, T. Suzuki and S.
Matsumura, 2001: Meiyu-Baiu front simulated in an AGCM (T42L52). The third international symposium on Asian Monsoon System, Okinawa, Japan, 322-327.

, — -1, and 2002:

Features of the Baiu front simulated in an AGCM (T42L52), J. Meteor. Soc. Japan, 80, 697-716.

Numaguti, A., S. Sugata, M. Takahashi, T. Nakajima and A. Sumi, 1997: Study on the Climate System and Mass Transport by a Climate Model. CCSR's supercomputer monograph report, National Institute for Environmental Studies, Environment Agency of Japan (Eds.), 3.

Peng, X. and K. Tsuboki, 1997: Impact of Parameterization on Mesoscale Precipitation Associated with the Baiu Front, J. Meteor. Soc. Japan, 75, 1141-1154.

Sato, K., T. Kumakura and M. Takahashi, 1999: Gravity waves appearing in a high resolution GCM simulation, J. Atoms. Sci., 56, 10051018.

Suzuki, S., 2001: On the relationship of a northward shift of the westerly jet at withdrawal of the Baiu and intraseasonal oscillation of Asian monsoon, the proceeding of development of global water model (in Japanese), 56-62.

Xie, P. and P.A. Arkin, 1996: Analyses of global monthly precipitation using gauge observations, satellite summaries, and numerical model predictions. J. Climate, 9, 840-858.

Yoshikake, T., F. Kimura and S. Emori, 2001: Numerical Study on the Baiu Front Genesis by Heating Contrast between Land and Ocean, $J$. Meteor. Soc. Japan, 79, 671-686.

Yoshizumi, S., 1977: On the structure of Intermediate-Scale Disturbances on the Baiu front. $J$. Meteor. Soc. Japan, 55, 107-120. 